\title{
Factors Influencing Debt Financing within State-owned Corporations in Kenya
}

\author{
*Micah Odhiambo Nyamita, Hari Lall Garbharran, Nirmala Dorasamy \\ Durban University of Technology, South Africa \\ *mnyamita@yahoo.com
}

\begin{abstract}
Debt financing is deemed crucial for economic development, as evidenced by the positive relationship between financial deepening and economic growth. Majority of studies on debt financing have been undertaken using data from developed economies, focusing more on private sector nonfinancial corporations. This study, therefore, attempts to fill the gap in the literature by investigating the factors influencing debt financing, using data from corporations within the public sector and from a developing economy. The study applied the fixed effects (FE), random effects (RE) and the general methods of moments (GMM), using the panel data regression analysis. Profitability, asset tangibility and corporation growth, were identified to be the main factors influencing debt financing within state-owned corporations in Kenya.
\end{abstract}

Keywords: Debt financing, financial leverage, debt financing theories, debt financing factors, state-owned corporations

\section{Introduction}

Debt financing is deemed crucial for economic development, as evidenced by the positive relationship between financial deepening and economic growth in the study of financial development and economic growth (Calderón \& Liu, 2003, p. 321). The information on the extent of borrowing within the state corporations is only available to government officials and, to a small extent, to the public through the legislative assemblies. Most of the reporting systems for the public sector in developing countries are still in the process of modernisation and this makes the availability of their financial information complicated. In recognition of this fact, studies on debt financing have been done mostly using data from developed economies with more private sector corporations (Foster \& Young, 2013, p. 6). This study, therefore, attempts to fill the gap in the literature by investigating the factors influencing debt financing within state-owned corporations in Kenya for the periods from 2002 to 2012. In the past decade, the financial sector has undergone much transformation in many countries around the world (Agca, De Nicolò and Detragiache, 2007:3). The technological changes and policies that reduce the administrative barriers of countries have led to increased access to foreign sources of finance. Most advanced and emerging economies have adopted banking sector reforms. The reforms have reduced or removed controls on interest rates and some state-owned banks have been privatised. In addition, policies to strengthen the bond and stock markets and their regulations have been undertaken by most countries with emerging economies, including Kenya (Ngugi, Amanja and Maana, 2006:1). These reforms have made debt financing popular among corporations, both in private and public sector. The study provides an analysis on how the debt financing patterns within the state-owned corporations in Kenya compare with the other patterns from developed economies using the available literature.

Kenya's recently developed public sector performance contracting system is supposed to improve efficiency and accountability within the state-owned corporations. The first medium-term 2008 - 2012 of vision 2030, which articulates government's commitment to facilitating public sector growth through enhanced good governance, makes the study of debt financing within the state corporations in Kenya important. The adoption of performance standards within the state-owned corporations in Kenya, aimed at integrating and aligning their performance to vision 2030, has not yet achieved the traction required (Republic of Kenya (2013, pp. xii-xiv). Therefore, there should be clear developed and enforceable strategic plans, such as debt financing strategies, and performance plans for the state-owned corporations in Kenya. These strategic plans would facilitate alignment of corporate mandates of state-owned corporations in Kenya with national development projects, which are linked to the Kenyan vision 2030. In addition, Fosu (2013, p. 140) argued that despite several decades of research in this area, there is no commonly accepted conclusion about the factors influencing debt financing decisions within the corporations. It is believed that debt financing decisions either hurt or boost the financial performance of 
a corporation (Campello, 2006, p. 168). The aim of this study, therefore, was to identify the factors influencing debt financing within the income-generating state-owned corporations in Kenya.

\section{Theories of debt financing}

In one of his early studies, Myers (2001, p. 81) argued that there is no universally accepted theory of debt-equity choice and there is no reason to expect one. Nevertheless, he assents to the fact that there are a number of conditional theories which have been established. The accepted theories start with the celebrated capital structure irrelevance proposition by Modigliani and Miller (1958, p. 268), developed in 1958. They argued in their first proposition that the market value of any firm is independent to its capital structure and is given by capitalizing its expected return at the rate appropriate to the risk class. Simply put, the debt financing level of the firm has no effect on the value of the corporation. The proposition was theoretically very sound but was based on the assumptions of perfect capital market and no tax world, which are not valid in reality. The Modigliani and Miller paper inspired serious research dedicated to challenging the irrelevance proposition as a matter of theory or as an empirical matter. These consequential researches have shown that the Modigliani-Miller theorem does not apply under a selection of conditions (Frank \& Goyal, 2005, p. 140). The most frequently adopted conditions include consideration of taxes, transaction costs, bankruptcy costs, agency conflicts, adverse selection, lack of division between financing and operations, time-varying financial market opportunities, and investor clientele effects.

Since so many different conditions that may affect debt financing levels within a corporation are available, it is not surprising that many different theories have been proposed after the Modigliani and Miller proposition. Most corporate finance literature point to the "trade-off theory", in which taxation and deadweight bankruptcy costs are taken into consideration (Frank \& Goyal, 2009, p. 1). Myers (1984, p. 581) proposed the "pecking-order theory" in which there is preference of retained earnings, debt and then equity. Frank and Goyal $(2009$, p. 1) argued that the idea that firms engage in "market timing" has also become popular, especially for publicly-traded corporations. Finally, the "agency theory" lurks in the background of much of the theoretical discussion. Agency concerns are normally included in the trade-off framework when deduced broadly. Each theory, however, has tried to explain the reasons behind the choice between debt financing and other forms of financing.

Trade-off theory: The term trade-off theory describes a host of related theories (Frank \& Goyal, 2005, p. 141). In all of these theories, the main goal is to maximize the corporation's value by determining the optimal debt financing level. According to the theory, a firm's optimal debt financing level is determined by a trade-off between the costs and advantages of borrowing, holding the firm's assets and investment plans constant (Myers, 1984, p. 578). It, therefore, means that the corporations will seek debt financing levels that balance the tax advantages of additional debt against the possible bankruptcy costs (Myers, 2001, p. 81). According to Myers, the trade-off theory is easily accepted because it explains why firms do not use excessive debt. On the other hand, Hackbarth, Hennessy and Leland (2007, p. 1389) argued that "existing trade-off models analyze the optimal amount of debt, but provide no guidance on debt structure, i.e. the mix of market versus nonmarket debt and specification of priority". After reviewing all the constraints of the trade-off models, Frank and Goyal (2005, p. 150) analysed the models into static and dynamic trade-off theories, and concluded that the trade-off class of models now appears to be much more promising than it did even just a few years ago.

Pecking order theory: The pecking order theory was developed by Myers and Majluf (1984, p. 187). According to their study, the debt financing level is driven by the desire of the corporation to finance new investments, first from retained earnings, then with low risk debt, and, finally, if all fails, with equity. The theory basically states that the corporation will use debt financing, rather than issuing equity, when internal cash flow is not sufficient to finance investment expenditure (Myers, 2001, p. 81). Unlike the trade-off theory, the pecking order theory does not have a well defined optimal level of debt financing, because there are two kinds of equity, internal (retained earnings) and external, one at the top of the pecking order and one at the bottom (Myers, 1984, p. 581). Myers, in this study, argued that the debt financing level of a corporation reflects its cumulative requirements for external finance. It is also not clear whether the firm will use all the available internal sources of finance first and at what point external equity is introduced. This is commonly referred to as information asymmetry problem. 
Market timing theory: Market timing is a relatively old concept in debt-financing decisions which is having a renewed surge of fame in the scholarly literature (Frank \& Goyal, 2009, p. 7). According to Baker and Wurgler (2002, p. 1), in corporate finance, market timing refers to the exercise of issuing shares at high prices and repurchasing them at low prices with an intention of exploiting temporary fluctuations in the cost of equity relative to the cost of debt capital. They believe that debt-financing level decisions change as a result of the cumulative outcome of past attempts to time the capital market. Managers, therefore, have benefits to time the market if they think it is possible and if they care more about current equity owners.

Agency theory: The agency theory focuses on the costs which are created due to conflicts of interest between shareholders, managers and debt holders. Basically, the argument is that debt financing requires managers to explain the investment details to debt providers and, therefore, expose themselves to monitoring by the debt investors (Frank \& Goyal, 2005, p. 154). Managers detest this process of their investments being exposed to screening and prefer retained earnings to external financing. Jensen and Meckling (1976, pp. 2-4) and others, like Harris and Raviv (1991, p. 300), Stulz (1990, p. 17) and Leland (1998, p. 1213), developed these concepts into the agency theory. The agency theory, therefore, suggests that a high debt-financing level reduces the agency costs of outside equity and increases the corporation's value by constraining or encouraging managers to act extra hard in the interests of shareholders (Berger \& Bonaccorsi di Patti, 2006, p. 1066). The debt financing level is determined by agency costs, which arise from conflicts of interests between the managers and the equity shareholders (Jiraporn, Kim, Kim and Kitsabunnarat, 2012: 210).

Other theories: Additional theories, to the aforementioned, have been highlighted in the recent past. Jensen (1986, p. 324) developed the free cash flow theory in which he argued that free cash flows allowed firms' managers to finance projects earning low returns which might not be funded by the equity or bond markets, hence, reducing debt financing. The free cash flow theory can be incorporated within the agency costs theory since it is argued that free cash flow reduces agency costs (Agrawal \& Jayaraman, 1994, p. 139). Myers and Majluf (1984, p. 219) contributed to the asymmetric information hypothesis in debt financing. They argued that asymmetric information problems drive the capital structure of firms since managers know more than the rest of the market about their firm's value (information asymmetry) and the market penalizes the issuance of securities, including debt, whose benefits related to the assessment of such information. Myers (1984, p. 577) incorporated the idea in the pecking order theory arguing that the pecking order theory predicts that companies should use stock issuances to cover financing deficits only as a last resort, after cheaper, less information-sensitive alternatives (like internal cash, bank debt, or public debt) have been exhausted.

Berger, Ofek, and Yermack (2012, p. 1414) highlighted that there are theoretical arguments and some empirical evidence that point to the possibility that managers can become entrenched, and that they may deviate from choosing optimal debt financing as a result. The argument is referred to as the managerial entrenchment theory, which suggests that entrenchment motives may cause managers to increase the debt-financing level beyond the optimal point, in order to inflate the voting power of their equity stakes and reduce the possibility of takeover attempts (Harris \& Raviv, 1988, p. 56). Since managerial entrenchment involves management control issues, it affects the agency costs, and can be lumped into the agency costs theory of debt financing. Research on debt financing theories is yet to be concluded (Myers, 2001, p. 81). This study is, therefore, an additional contribution to the wealth of financial management epistemology already in existence in the area of debt financing.

Factors influencing debt financing: There are extensive studies on factors influencing debt financing within private-sector corporations. However, very few or none has been applied entirely on state-owned corporations, more so from Kenya. The few studies, such as Majumdar and Chhibber (1999, p. 291); Dewenter and Malatesta (2001, p. 320); King and Santor (2008, p. 2426); Huang and Song (2006, pp. 1617) and Lim (2012, p. 191), that have attempted to look at the factors influencing debt-financing decisions within state-owned corporations, have only concentrated on stock exchange-listed corporations, which included some state-owned corporations which are listed in the stock exchange. However, the factors that influence debt-financing choice remain indefinite despite much theoretical literature and the reassurance of decades of empirical tests (Frank \& Goyal, 2009, p. 1). A number of studies, like Jõeveer (2013, p. 294); De Jong, Kabir, and Nguyen (2008, p. 1954); Kayo and Kimura (2011, p. 358) and Frank and Goyal (2009, p. 3), categorised the factors that influence debt financing into corporation characteristics or specific factors, macroeconomic factors or country specific factors. Corporation specific factors are those factors 
which are distinct to each individual corporation, while macroeconomic factors are economic factors of the country which have a common effect to all the corporations within the country.

Corporation factors: Corporation specific factors have remained the main focus of debt financing studies (Kayo \& Kimura, 2011, p. 358) from the second proposition of Modigliani and Miller (1963, p. 434) to the current studies, like Jõeveer (2013, p. 294); Majumdar (2012, p. 22); Frank and Goyal (2009, p. 3); Antoniou, Guney, and Paudyal (2008, p. 59) and Deesomsak, Paudyal and Pescetto (2004: 387). The corporation specific factors influencing debt financing from the above studies, include corporation profitability, corporation size and growth, nature of assets, non-debt tax shields, liquidity and probability of bankruptcy. Other corporation factors, like corporation tax rates, business risk, access to capital markets, the finance manager's gender and the composition of the board of directors, are also considered to have influence on debt financing (Jõeveer, 2013, p. 103); (Antoniou et al., 2008, p. 77).

Profitability: Profitable corporations are believed to face reduced expected costs of financial distress and find interest-tax benefits more important (Frank \& Goyal, 2009, p. 7). Therefore, the tax benefit and the bankruptcy costs' perspective predict that profitable corporations should use more debt. However, the benefit is expected to be low within the state-owned corporations in Kenya, since most of them are exempted from taxation. In addition, the agency costs' perception expects that the restraint provided by debt financing is more valuable for profitable corporations since these corporations are prone to having stern free cash-flow problems (Jensen, 1986, p. 324). In contrast, profitable state-owned corporations in Kenya may borrow less to avoid the restraint provided by debt financing in the process of serving the political interests. On the other hand, Deesomsak et al. (2004, p. 394) argued that they expect an inverse relation between profitability and debt financing levels since the pecking-order theory suggests that managers prefer to finance investments internally because of the informational asymmetry between managers and outside investors. Thus, profitable corporations will prefer not to raise external funds in order to avoid potential dilution of ownership and additional external monitoring. The theory of debt financing and profitability, therefore, predicts both a positive relationship, which supports the trade-off theory, and a negative relationship which supports the pecking order theory (Kayo \& Kimura, 2011, p. 360). The empirical findings discussed below confirm the same argument and this study shows which of the hypotheses are adopted by the Kenyan state corporations.

Corporation size: The corporation size is also a very important factor that influences a corporation's debt financing decision (Kayo \& Kimura, 2011, p. 360). The trade-off theory suggests a positive relation between corporation size and debt financing level, since larger corporations have been revealed to have lower bankruptcy risk and relatively lower bankruptcy cost (Deesomsak et al., 2004, p. 394). The larger corporations may also be more diversified (Titman \& Wessels, 2012, p. 6). In addition, Deesomsak, Paudyal and Pescetto argue that large corporations have lower agency costs of debt, relatively smaller monitoring costs, less volatile cash flows, easier access to credit market, and require more debt to fully benefit from the tax shield. Therefore, according to this hypothesis, corporation size is expected to have a positive impact on debt-financing level. Furthermore, larger companies, believed generally to be more transparent, tend to have larger debt levels and can issue larger amounts of debt, thus allowing them to spread the issuing costs (Byoun, 2008, p. 3077). However, Rajan and Zingales (1995, p. 1451) argued that this relationship could be either positive or negative. Their positive relationship argument supports the above trade-off suggestion, while, for the negative relationship, they say that asymmetric information problems are likely to be smaller in larger corporations. Thus, it would be possible for larger corporations to issue new shares instead of debt financing without a reduction in their market values. However, with the low activity and efficiency within the capital market in Kenya, the state-owned corporations raise funds through grants and issuing more shares to the government and other government agencies. Again, by testing the relationship between firm size and debt financing, there are two possible results supported by different theoretical perceptions. A positive relationship indicates the importance of diversification and the negative relationship advocates for the role of information asymmetry.

Corporation nature of asset (tangibility): It is believed that corporations operating with more tangible assets have a higher debt capacity (Byoun, 2008, p. 3077). Kayo and Kimura (2011, p. 360) suggested that asset tangibility plays an important role on debt financing decisions since the collateral capability of tangible assets in place tend to increase debt-financing levels. In addition, the agency theory proposes that corporations with high debt-financing levels tend to under invest, or invest below their optimal investment levels, and thus transfer wealth away from debt holders to equity holders (Deesomsak et al., 2004, p. 392). They argued that these low optimal investment levels and transfer of wealth to equity 
holders will cause debt holders to require collateral because the use of secured debts can help alleviate this problem. They also argued that the liquidation value of the firm increases with the tangibility of assets and decreases the probability of mispricing in the event of bankruptcy. Therefore, the existence of tangible assets within the corporation's assets serves two critical purposes; it enables the corporation to pledge them as collateral, thereby, reducing the agency costs of debt, like risk shifting, and, at the same time, protects the debt holder in the event of liquidation (Rajan \& Zingales, 1995, p. 1451). It means that corporations with difficulties in providing collaterals are prone to pay the higher interest, or may be forced to issue equity instead of debt finance, which implies a positive relationship between tangibility of assets and debt financing. Asset tangibility can also discourage debt financing since a larger proportion of tangible assets in a corporation's asset portfolio is expected to reduce supply-side constraints (Majumdar 2012, p. 5). According to Frank and Goyal (2009, p. 9), the pecking order theory makes opposite predictions since low information asymmetry associated with tangible assets makes equity issuances less costly. This may be the case for state-owned corporations in Kenya with higher tangibility, since the political influence may not allow them to use their assets as collateral. Thus, debt-financing levels should be lower for state-owned corporations with higher tangibility.

Corporation growth: Generally, theoretical studies suggest that corporation growth opportunities are negatively related with debt-financing levels (Huang \& Song, 2006, p. 20). Growth increases costs of financial distress, reduces free cash-flow problems, which the corporation managers tend to protect, hence, making worse debt financing related agency problems (Frank \& Goyal, 2009, p. 8). According to the authors, growing corporations put a lot of emphasis on investments that benefits the shareholders; hence, the trade-off theory predicts that growth reduces the debt financing level. Titman and Wessels (2012, p. 4) agreed with this argument and suggested that the cost associated with the agency relationship is expected to be higher for corporations in growing industries, which have more flexibility in their choice of future investments. Therefore, the expected future growth should be negatively related to debt financing levels. Deesomsak et al. (2004, p. 394) put it more simply that higher growth opportunities give more benefits to invest sub-optimally, or to accept risky projects that take wealth from debt holders. This, they argued, raises the cost of borrowing, especially amongst the state-owned corporations, and thus, growing corporations tend to use internal resources or equity capital rather than debt. In addition, the state-owned corporations in Kenya, with high growth and whose value comes from intangible growth opportunities, may not want to commit themselves to debt servicing as their revenue may not be available when needed.

Nevertheless, growth opportunities can also compare positively with leverage, in line with the pecking order presumption (Kayo \& Kimura, 2011, p. 359). According to Frank and Goyal (2009, p. 8), the pecking order theory implies that corporations with more investments, holding profitability constant, should accumulate more debt over time. Thus, growth opportunities and debt financing are positively related under the pecking order theory. In addition, the pecking order of debt-financing decisions derives from the asymmetric information between managers and investors (Kayo \& Kimura, 2011, p. 359). In terms of asymmetric information propositions, Myers and Majluf (1984, p. 219) argued that managers tend to issue new shares when prices are overvalued, thus benefiting old shareholders. This scenario may cause new shareholders to demand a discount on the new shares price and result in managers avoiding the issuing of new shares, even though this decision can make firms ignore profitable investments. This behaviour, therefore, may increase issue of debt instead of equity, thus increasing debt financing levels. However, the asymmetric information propositions may not work perfectly in Kenya due to the low efficiency within the stock market.

Corporation risk: Corporation risk or volatility is a measure for the probability of financial distress and it is generally expected to be inversely related with the debt-financing level (Huang \& Song, 2006, p. 20). According to Frank and Goyal (2009, p. 10), corporations with more volatile cash flows face higher expected costs of financial distress and should use less debt. Furthermore, volatile cash flows are capable of reducing the probability of tax benefits being used. Therefore, higher risk should result in low debt financing under the trade-off theory. Deesomsak et al. (2004, p. 394), looking at corporation risk from the point of corporation's earning, argued that higher volatility of earnings increases the probability of financial distress, since corporations may not be able to fulfil their debt-servicing contacts. This implies that the debt-financing level of a corporation decreases with increase in earnings volatility, leading to an expected inverse relationship. This may be the case for the state-owned corporations in Kenya, which are believed to have a strong political influence in their management practice (Njeru, 2013, p. 3). In their further analysis of the risk corporation, Frank and Goyal (2009, p. 10) suggested that it should be 
expected that corporations with volatile equity shares are those which are very risky, and such corporations may suffer more from adverse selection in the stock markets. Therefore, according to the pecking order theory, these corporations, being riskier because of their volatile stocks, would predict a higher debt-financing level. In addition, Frank and Goyal (2009, p. 10) argued that even corporations with volatile cash flows might need to periodically access the external capital markets, thereby increasing debt financing levels.

Corporation tax rate: Corporation tax rates should influence debt financing since debt-interest payments are typically tax deductible whereas dividends payments are not (Antonczyk \& Salzmann, 2014, p. 136). It is, therefore, logical that higher tax rates, like in Kenya, will imply greater interest tax shield benefits and, consequently, induce more debt financing rather than equity financing (Jõeveer, 2013, p. 295). This reasoning is the main theme of a pioneering study by Modigliani and Miller (1963, p. 434) and almost all researchers now believe that corporation taxes should be significant to a corporation's debt financing decisions (Huang \& Song, 2006, p. 19). However, for state-owned corporations, especially in Kenya, which sometimes get tax subsidies from the government, may not have greater interest tax shield benefits and hence, less use of debt financing.

Liquidity: Theoretically, corporations with more liquid assets can use them as another internal source of funds instead of debt, leading to lower debt-financing levels, according to the pecking order theory (Öztekin \& Flannery, 2012, p. 91). In addition, managers can manipulate liquid assets in favour of shareholders against the interest of debt holders which increases the agency costs of debt financing and reduces debt-financing levels (Deesomsak et al., 2004, p. 394). The is most probable within state-owned corporations in Kenya, where the politically appointed managers may use the liquid assets in favour of the government (shareholders) and avoid debt financing which increases agency costs.

Non-debt tax shield: Other items, apart from interest expenses, that contribute to tax payments decrease, for example, the tax deduction for depreciation and provision for bad debts are labelled as non-debt tax shields (Bauer, 2004, p. 163). According to DeAngelo and Masulis (1980, p. 21), corporations that have non-debt tax shields are likely not to use fully the debt-tax shield that comes from debt interest. In other words, corporations with sufficient investments, tax credits or depreciation deductions are likely to use less debt financing (Kouki \& Said, 2012, p. 220). The may be the case for state-owned corporations in Kenya, with less debt tax shield benefits. They may use non-debt tax shields as substitutes for a debtrelated tax shield and, therefore, the relationship between non-debt tax shields and debt financing should be negative (Lim, 2012, p. 195).

Probability of bankruptcy: Higher probability of bankruptcy implies high bankruptcy costs; hence, the trade-off hypothesis predicts a negative relationship between probability of bankruptcy and debt financing (Kayo \& Kimura, 2011, p. 360). In addition, the greater political influence within the stateowned corporations in Kenya also increases the probability of bankruptcy and keeps away the debt providers. However, larger corporations are often more diversified and have more stable cash flow. Therefore, the probability of bankruptcy for large firms is smaller compared with smaller ones (Titman \& Wessels, 2012, p. 6). Thus, according to the pecking order hypothesis, larger profitable firms should use more of their internally generated funds; reducing the debt-financing levels. The pecking order argument implies that large corporations with less probability of bankruptcy can have less debt-financing levels.

Macroeconomic factors: Macroeconomic factors are regional or national economic factors which externally influence the corporation's financial strategies, including debt financing decisions. Financial management literature recognizes the important role that macroeconomic factors play in the determination of capital structure decisions of firms (Lemma \& Negash, 2013, p. 1089). Recent and past literature identifies the gross domestic product (GDP), inflation rate, interest rate, financial institutions' activities and industry median as the common macroeconomic factors which have an influence on the debt-financing decisions of corporations (Mokhova \& Zinecker, 2014, p. 533; (Baltacı \& Ayaydın, 2014, p. 50; Lemma \& Negash, 2013, p. 1090; Jõeveer, 2013, p. 103; Kayo \& Kimura, 2011; Frank \& Goyal, 2009, p. 3; Deesomsak et al., 2004, p. 395).

Gross domestic product: It is believed that a country's economic development level reflects the wealth disparity between them, and, hence, access to finance including debt financing (Lemma \& Negash, 2013, p. 1090). During expansions, stock prices go up, expected bankruptcy costs go down, taxable income goes up, and cash increases, which leads to more debt financing within corporations (Frank \& Goyal, 2009, p. 
11). Frank and Goyal (2009, p. 11) further argued that, during expansion, the corporations' assets will increase and if corporations borrow against collateral then debt financing levels should increase. Therefore, according to Jõeveer (2013, p. 298), the gross domestic product rate, which is used as a proxy for growth opportunities, should have a positive relationship with debt-financing levels of corporations. However, Mokhova and Zinecker (2014, p. 533) argued that the boost in economy and, consequently, growth in the gross domestic product will lead to an increase in corporations' profits. According to the pecking order theory, corporations will prefer internal sources of financing, thereby causing reduction in debt-financing levels. Frank and Goyal (2009, p. 11) also noted that if the pecking order theory holds, then debt financing should decline during expansions since internal funds increase during expansions and agency problems between shareholders and managers are less severe. Consequently, corporations should issue less debt. In contrast, state-owned corporations, especially in Kenya, also have social and political objectives to pursue; economic development level reflected by the gross domestic product may not have influence in the wealth disparity between them. Hence, gross domestic product may have no effect on their access to finance including debt financing.

Inflation rate: Inflation is considered one of the main indicators of a country's stability and increase in the inflation rate causes uncertainty in economic conditions (Baltacı \& Ayaydın, 2014, p. 50). The authors argued that this uncertainty causes inability of corporations to repay their debts. Gungoraydinoglu and Öztekin (2011, p. 1467) also argued that higher inflation decreases the benefits of debt financing because of higher bankruptcy costs of debt imposed on corporations. In addition, Drobetz, Gounopoulos, Merikas and Schröder (2013: 67) argued that, in periods with higher inflation rates, corporations use currently weak currencies to repay debt and, in turn, lower their debt-financing levels. It is, therefore, expected that inflation rates should be negatively related to corporations' debt financing levels. On the other hand, Jõeveer (2013, p. 295) maintained that the expected inflation is predicted to be positively related to debt financing due to higher real value of tax deductions on debt. In support of a positive relation, Frank and Goyal (2009, p. 11) argued that market timing in debt markets also results in a positive relation between expected inflation and debt financing if managers issue debt when expected inflation is high relative to current interest rates. In Kenya, the inflation rates have not been stable since 2007, and it will be important to find its effect on debt financing for most state-owned corporations.

Interest rates: In the presence of other variables such as taxation and bankruptcy costs, changes in interest rates can influence debt financing levels within a corporation, since corporations are more likely to use debt when the cost of borrowing is low (Deesomsak et al., 2004, p. 395). They argued that, under this hypothesis, the level of interest rates is expected to be negatively related to debt-financing levels. Deesomsak et al. (2004, p. 395) further noted that interest rates also incorporate inflation expectations and, therefore, corporations could be expected to change from equity to debt financing when interest rates are increasing. In this case, the level of interest rates is expected to be positively related to leverage. As aforementioned, the interest rates in Kenya showed an increasing trend over the five-year period2007 to 2011, and it will be important to determine its effect on debt financing within state-owned corporations.

Industry median: It would be logical to expect that specific characteristics of a given industry could also influence the debt-financing decisions of corporations (Baltacı \& Ayaydın, 2014, p. 51). Frank and Goyal (2009, p. 8) argued that corporations in an industry face common factors that affect their financing decisions and these could reflect on product-market interactions or the nature of competition. It could also reflect on industry heterogeneity in the types of assets, business risk, technology or regulation. Therefore, according to the authors, while looking at industry median in terms of growth, the trade-off theory predicts that higher industry median growth should result in less corporation debt financing. However, in terms of industry debt-financing levels, higher industry median debt levels should result in more corporation debt financing. Frank and Goyal $(2009$, p. 8) further looked at the corporations in terms of industry regulations. The authors argued that regulated corporations have stable cash flows and lower expected costs of financial distress. Therefore, they should have more debt. However, managers have less discretion in regulated corporations, which reduces the severity of shareholder-manager conflicts and makes debt financing less desirable from a control perspective. They concluded that the trade-off theory makes an ambiguous prediction on the effect of regulation on leverage. Secondly, under a pure pecking order perception, the industry should only matter to the extent that it serves as a proxy for the financing deficit of a corporation, making it an indirect link. Thirdly, under the market timing theory, the industry should matter only if valuations are correlated across firms in an industry. 
Financial or debt market conditions: The literature also considers the level of conditions of financial institutions as another important factor that influence debt-financing decisions of a corporation (Lemma \& Negash, 2013, p. 1089). De Jong et al. (2008, p. 1954) argued that, when a bond market in a given country is highly developed, issuing and trading bonds are easier and leads to higher levels of corporate debt financing. In contrast, they also acknowledged that, when the stock market is developed, the debtfinancing level of corporations tends to be lower because the broader supply of funds decreases the cost of equity. Deesomsak et al. (2004, p. 395) also noted that financial market development plays an important role in the debt-financing choice of a corporation. They argued that, as stock-market activity increases, preference of corporations for equity over debt also increases. Therefore, stock-market activity is expected to be inversely related to debt financing. However, the stock market in Kenya has remained more active with equity issues than debt financing securities. This may discourage corporations, such as state-owned corporations, from venturing into stock-market debt instruments, like bonds, as a means of debt financing.

Other factors: Additional institutional factors should be included as alternative measures of the severity of asymmetric information (Jõeveer, 2013, p. 103). In his study, Jõeveer (2013, p. 103) included the corruption index of corporations and argued that it is expected that the higher the corruption perception index (means lower corruption), the less severe is the asymmetric information problem. Hence, the positive relation between the corruption index and the debt-financing level is expected. Jõeveer (2013, p. 155) and Bassey, Arene, and Okpukpara (2014, p. 44) also studied the effect of the age of the corporation and debt financing and found that they are negatively correlated. This study investigated the abovementioned macroeconomic factors and corporation specific factors.

\section{Methodology}

Research design: The study used a combination of the descriptive and explanatory research design. It applied a hybrid of cross sectional and longitudinal quantitative surveys. Rindfleisch, Malter, Ganesan and Moorman (2008: 276), in their study of cross-sectional versus longitudinal, argued that both the designs have limitations and a combination will give a strong output. Therefore, the combination of the techniques allowed the researcher to investigate factors influencing debt financing across state-owned corporations over a period of eleven years from 2002 to 2012.

Research model: Since the study used a combination of cross-sectional and longitudinal data, a panel data regression model was used (Daskalakis \& Psillaki, 2008, p. 91). According to the authors, a panel data regression model reduces co-linearity among the explanatory variables, thus improving the efficiency of econometric estimates. Secondly, they argued that panel data models can take into account a greater degree of the heterogeneity that characterizes corporations. Thirdly, panel models also allow for the presence of dynamic effects. According to Kayo and Kimura (2011, p. 365), studies on factors of corporation debt financing use the simple regression or empty model to analyse the panel data. Cortez and Susanto (2012, p. 128) argued that panel data regressions are run in order to test the strength of the relationship between debt financing and the potential factors influencing it within the corporations. The data is grouped into their respective source (i.e., panel variable: corporation) and listed according to their respective time period (i.e., time variable: year). The panel regression model is further believed to give a small standard error of estimate compared to the aggregate ordinary least squares method (Petersen, 2009 , pp. 437, 473). Therefore, in the identification of factors influencing debt financing, the study used a multiple linear panel data regression model 1 , which has been applied by most studies such as Deesomsak et al. (2004, p. 392); Huang and Song (2006, p. 27); Oyesola (2007, p. 19); Antoniou et al. (2008, p. 69); Gungoraydinoglu and Öztekin (2011, p. 1461); Cortez and Susanto (2012, p. 128); Lim (2012, p. 196); Moosa and Li (2012, p. 7); Smith (2012, p. 146); Chakraborty (2013, p. 113); Drobetz et al. (2013, p. 59); Lemma and Negash (2013, p. 1092); (Alzomaia, 2014, p. 62) and (Bassey et al., 2014, p. 41). The applied multiple regression panel data model is of the form:

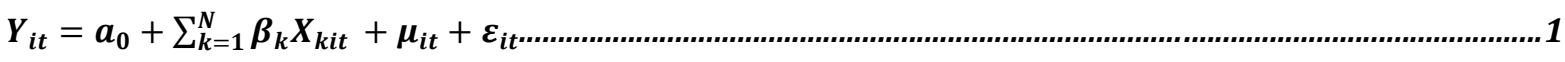

Where $\boldsymbol{Y}_{i t}$ is a measure of debt financing (financial leverage) of firm $i$ in year $t$ and $X$ represents the measure of explanatory variables (firm specific factors and macroeconomic factors). $\mu$ represents unobserved factors (either firm-specific or macroeconomic) and $\alpha_{0}$ is the constant. $\beta$ form $k=1$ to $N$ are unknown parameters to be estimated. The measure of explanatory variables $X$ includes $k$ factors which are the total number of all factors influencing debt financing observed in this study. The explanatory 
variables and their respective measures are given in table 4.1. The explanatory variables include both the firm-specific factors and macroeconomic factors.

Research variables and measures: Under model 1 above, which is used to identify factors influencing debt financing of state corporations, the debt financing variable (financial leverage) is a dependent variable. Different empirical measures have been used to show debt financing levels within corporations (Frank \& Goyal, 2009, p. 2). They argued that some scholars advocate for book leverage, which is the proportion of corporation debt finance to the total book value of the assets of the corporation. Others scholars advocate for market leverage, which is the proportion of corporation debt to market value of the corporation. Since Fama and French (2002, p. 9) and Rajan and Zingales (1995, p. 1429) suggested that reliance on book leverage is not a serious limitation and most of the state corporations in Kenya are not listed in the stock exchange, this study applied the book leverage and definitions of debt, i.e., long-term, short-term and total debt, as debt financing level proxies. As summarised in table 4.1, the study used book values to measure long-term debt leverage (LDL) using long-term debt of the state corporation divided by the total assets, short-term debt leverage (SDL) using short-term debt of the state corporation divided by the total assets and, total debt leverage (TDL) using total debt of the state corporation divided by the total assets. The factors influencing debt financing decisions within corporations, being explanatory (independent) variables in model 1, have been measured using different proxies as shown in Table 1.

Table 1 : Research variables and measures

\begin{tabular}{|c|c|c|}
\hline Variable & Measure & Formulae (Proxy) \\
\hline \multicolumn{3}{|c|}{ Debt financing levels (financial leverage) } \\
\hline Total debt leverage & TDL & Total debt/Total assets \\
\hline Long-term debt leverage & LDL & Long-term debt/Total assets \\
\hline Short-term debt leverage & SDL & Short-term debt/Total assets \\
\hline \multicolumn{3}{|c|}{ Factors influencing debt financing } \\
\hline Profitability & PROF & Operating profit/Annual sales \\
\hline Corporation size & SIZ & Natural logarithm of total assets \\
\hline Asset tangibility & TANG & Tangible assets/Total assets \\
\hline Corporation growth & GROW & Percentage $(\%)$ change in total assets \\
\hline Corporation risk & RISK & Standard deviation of operating profits/Total assets \\
\hline Corporation tax rate & TAX & Income tax charge/Profit before tax \\
\hline Liquidity & LIQ & Current assets/Current liabilities \\
\hline Non-debt tax shield & NDTS & Depreciation charge/Operating profit \\
\hline Probability of bankruptcy & $\mathrm{BKCY}$ & Interest charge/Operating profit \\
\hline Gross domestic product & GDP & Annual GDP of the country \\
\hline Inflation rate & INFL & Annual average inflation rate \\
\hline Interest rates & INT & Annual average commercial banks lending rates \\
\hline Industry median & INDM & Mean of long-term debt leverage \\
\hline Financial markets conditions & FMC & Market capitalization \\
\hline Age & AGE & Number of years in existence \\
\hline
\end{tabular}

Table 1 represents the research variables and measures, followed by their proxies.

Research Hypotheses: The research hypotheses were as follows:

- $\quad \mathrm{H}_{0} 1$ : Profitability influences debt financing negatively;

- $\quad \mathrm{H}_{0} 2$ : Corporation size influences debt financing positively;

- $\quad \mathrm{H}_{0} 3$ : Asset tangibility influences debt financing positively;

- $\quad \mathrm{H}_{0} 4$ : Corporation growth influences debt financing negatively;

- $\quad \mathrm{H}_{0} 5$ : Corporation risk influences debt financing negatively;

- $\mathrm{H}_{0}$ 6: Corporation tax rate influences debt financing negatively;

- $\quad \mathrm{H}_{0}$ 7: Liquidity influences debt financing negatively;

- $\quad \mathrm{H}_{0} 8$ : Non-debt tax shield influences debt financing negatively; 
- $\quad \mathrm{H}_{0}$ 9: Probability of bankruptcy influences debt financing positively;

- $\quad \mathrm{H}_{0}$ 10: Gross domestic product influences debt financing positively;

- $\quad \mathrm{H}_{0} 11$ : Inflation rate influences debt financing negatively;

- $\quad \mathrm{H}_{0}$ 12: Interest rate influences debt financing negatively;

- $\quad \mathrm{H}_{0}$ 13: Industry median influences debt financing positively;

- $\quad \mathrm{H}_{0}$ 14: Financial market conditions influence debt financing positively; and

- $\mathrm{H}_{0}$ 15: Corporation age influences debt financing positively.

Target Population and sample size: The population of this study was defined in terms of the number of state-owned corporations established by the Acts of Parliament in Kenya as at June 30, 2011. The population frame data was from the office of the Inspector General in charge of state corporations under the Ministry of Public Service in the office of the Prime Minister of Kenya. According to this data, there are 206 established state corporations in Kenya, out of which 50 are income-generating corporations (Stateowned corporations). Hence, the target population for this study was made up of the 50 incomegenerating state corporations in Kenya as at $31^{\text {st }}$ December 2011. The sample size for the study is made up of all the 40 income-generating corporations, selected from the general population using nonprobability sampling technique. The non-income generating corporations are excluded from the study, since their financial performance is not profit based and may not be influenced by market-oriented decisions, such as debt financing strategies. Struwig and Stead (2013, p. 116) argued that the nonprobability sampling technique should be used in special cases, usually when the population has much in common, like the case of income-generating state corporations. In addition, in selecting the respondents within the target population, a census study was applied to collect data for all the 50 income-generating state corporations.

Data collection and analysis: The secondary data was the main source of information in this study, and, the primary data, from the questionnaires, were only used to provide clarity, where needed. Houston (2004, p. 154) argued that secondary data measures are widely accepted and strongly preferred over selfreport scale measures, i.e., primary data, in finance discipline, in which this study falls. However, the study also used the primary data to improve the reliability and validity of the test scores. A regression analysis was done using the conceptual model 1 previously mentioned to identify the factors influencing debt financing of state-owned corporations. In addition, to establish the significance of the variables in each of the regression models, the $t$-test was applied at $90 \%, 95 \%$ and $99 \%$ levels of confidence. The common regression model estimator, from the reviewed literature, appears to be the pooled ordinary least squares (OLS) method and the generalized method of moments (GMM). However, this study estimated the coefficients of multiple regression model 1 using the independent and dependent variables of the study, through the fixed effects (FE), random effects (RE) and GMM system panel regression models. According to Bond (2002, pp. 141-142), panel data models have an advantage over pooled ordinary least squares (OLS) model since the former incorporates the cross-sectional and longitudinal variables of the model. The panel data advantages over pooled ordinary least squares (OLS), therefore, include the possibility that underlying microeconomic dynamics (heterogeneity) may be concealed by pooling biases, and the scope panel data offers to investigate heterogeneity in adjustment dynamics between different types of individuals, household or corporations.

On the other hand, Lemma and Negash (2013, p. 1092) argued that empirical literature favours fixed effects (FE) over random effects (RE) in basic debt-financing research, since the fixed effects allow for controls on biasness that may be caused by the corporation's specific characteristics and time effects. However, fixed effects assume that the time-invariant characteristics are unique to the specific corporation and should not be correlated with other corporation's characteristics. Therefore, each corporation is assumed to be different and the corporation's error term and the constant (which captures individual corporation's characteristics) should not be correlated with each other. If the error terms are correlated i.e., endogeneity exists, then fixed effects model is not suitable since inferences may not be correct, therefore, there is need to model the relationship by using either random effects or GMM. The Hausman test is applied to test whether the error terms are correlated with the constants. If the test is significant, at $95 \%$ level of confidence $(\mathrm{p}<0.05)$, then there is no correlation and the fixed effects model figures are reliable. However, Greene (2008, p. 183) argued that if there is reason to believe that differences across entities (corporations) have some influence on the dependent variables (like in this case financial leverage or financial performance), then the random effects method is appropriate. In addition, random effects allow for the inclusion of time invariant variables, such as gender. In contrast, the random effects model assumes that the individual (variables) characteristics are not correlated by the 
time effects (i.e., there is no autocorrelation or serial correlation) and there is need to specify those individual (corporation's) characteristics that may or may not influence the predictor variables. The problem with this is that some variables may not be available, therefore, leading to omitted variable bias in the model. All the same, the random effects model allows for generalization of the inferences beyond the sample used in the model.

As aforementioned, it has been observed that endogeneity is a common problem that econometric model research, such as debt financing, has to deal with. In regard to this observation, Lemma and Negash (2013, p. 1092) argued that modern debt-financing research should apply system-GMM procedures, which are robust to data endogeneity problems (Antoniou et al., 2008, p. 61; Baltacı \& Ayaydın, 2014, p. 51; Dang, 2013, p. 175; Gaud, Hoesli, \& Bender, 2007, p. 206; Gaud, Jani, Hoesli, \& Bender, 2005, p. 58; Gungoraydinoglu \& Öztekin, 2011, p. 1462; Mateev, Poutziouris, \& Ivanov, 2013, p. 42; Öztekin \& Flannery, 2012, p. 90). In other words, the system-GMM estimator controls for the presence of unobserved firm-specific effects and for the endogeneity of explanatory variables (Mateev et al., 2013, p. 42). According to Bond (2002, p. 160), the system-GMM method is particularly useful when the panel regression model of interest contains endogenous or predetermined explanatory variables, but the processes generating these series are not completely specified. Therefore, a specification test is done to show that the excluded variables have explanatory power for the right-hand-side endogenous variables, the instruments are uncorrelated with the error term and that the exclusion restrictions are valid. Lastly, the specification test helps to show that there are endogenous explanatory variables in the model since system-GMM is inefficient relative to OLS if all variables are exogenous.

Further, the system-GMM estimator can be used to obtain consistent parameter estimates in a wide range of micro-econometric applications, including debt financing strategies of state-owned corporations. However, Bond (2002, p. 160) noted that the estimator may be subject to large finite sample biases when the instruments available are weak, and this is particularly likely to be a problem when using the basic first differenced estimator with series that are highly persistent, like the case in this study. Therefore, a careful comparison of the consistent of system-GMM regression estimator results with other panel regression models, like fixed effects and random effects, can help in avoiding more biases in the study results. In addition, the use of these different panel data regression estimator models helped to check the robustness of the results. Under the system-GMM estimator procedure, the form of panel regression equation 1, for factors influencing debt financing, and equation will be changed into equation 2 .

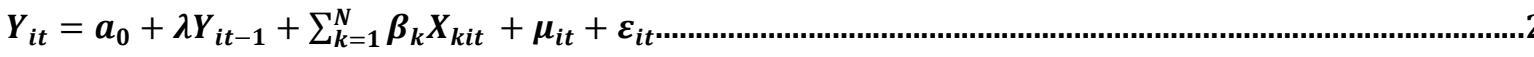

Where the new variable $\boldsymbol{Y}_{\boldsymbol{i t}-\mathbf{1}}$ is the lagged value of the dependent variable, i.e., lagged value of financial leverage for equation 1, with its coefficient $\lambda$. The presence of the lagged dependent variable $\boldsymbol{Y}_{\boldsymbol{i t}-\mathbf{1}}$ controls for autocorrelation or serial correlation within the dependent variables.

In addition, the regression analysis process required data cleaning in order to achieve better results. Since, the debt financing procedures of state-owned corporations within the financial sector are unique, the data from nine state-owned corporations from the financial sector were excluded from the regression analysis (Alzomaia, 2014, p. 59; Lemma \& Negash, 2013, p. 1093). Further, for a better trend analysis, the data from financial statements used in the regression analysis included figures for the eleven-year period from 2002 to 2012, subject to availability of the statements. The data analysis was done using both the Statistical Package for the Social Sciences (SPSS) and Data analysis and Statistically Software (STATA). The SPSS software was used for the analysis of primary data from the questionnaires and STATA software was used for the analysis of secondary panel data for the fixed effects, random effects and system-GMM regression models. In the analysis of GMM panel data regression model, the Arellano-Bond GMM estimator in STATA software was applied, since, in addition to the aforementioned benefits of using system-GMM estimator, it was designed for small-time series (T), in this case a minimum of 3 years and a maximum of 11 years, and large cross-sectional individual observations $(\mathrm{N})$, in this case, 31 non-financial state-owned corporations.

\section{Results}

Regression analysis descriptive statistics: The regression analysis process required data cleaning in order to eliminate outliers that may influence results. Since the debt financing procedures of state-owned corporations within the financial sector are unique, the data from these nine state-owned corporations were excluded from the regression analysis (Alzomaia, 2014, p. 59; Lemma \& Negash, 2013, p. 1093). 
Further, for a better trend analysis, the data from financial statements used in the regression analysis included figures for the eleven-year period from 2002 to 2012, subject to availability of the statements. Table 2 demonstrates the summary statistics for the regression analysis used for identifying factors influencing debt financing, determining the relationship between debt financing and financial performance, and identifying the debt financing theories applicable within the state-owned corporations in Kenya.

Table 2: Regression analysis summary statistics

\begin{tabular}{lllll}
\hline Variable & Mean & Std. Dev. & Min & Max \\
\hline TDL & 0.6407 & 0.7099 & 0.0014 & 2.8261 \\
LDL & 0.3374 & 0.5696 & 0 & 2.6522 \\
SDL & 0.3052 & 0.3950 & 0.0013 & 2.75 \\
PROF & -0.1229 & 1.4411 & -18.25 & 0.9647 \\
SIZ & 22.3640 & 1.6479 & 16.8112 & 25.7984 \\
TANG & 0.5358 & 0.2407 & 0 & 0.9583 \\
GROW & 15.6531 & 47.6608 & -47.6379 & 350.007 \\
RISK & 0.0797 & 0.1232 & 0 & 1 \\
TAX & 0.1671 & 0.7842 & -2 & 9.0243 \\
LIQ & 4.8742 & 14.8634 & 0.0142 & 191.0231 \\
NDTS & 1.1039 & 9.5492 & -4.5161 & 131.25 \\
BKCY & 0.3913 & 3.2122 & -1.0769 & 44.3750 \\
GDP & 4.4045 & 1.9252 & 0 & 7.1 \\
INFL & 11.6149 & 6.9892 & 0 & 26.2 \\
INT & 15.2060 & 2.6523 & 0 & 20.04 \\
INDM & 0.5154 & 0.5992 & 0 & 5.0394 \\
AGE & 3.1930 & 0.8012 & 0 & 4.1896 \\
\hline
\end{tabular}

As shown in Table 2, the number of state-owned corporations for the regression analysis reduced to 31 , which makes up $62 \%$ of the target population and $77.5 \%$ of the study sample size. Further, the maximum observations for each variable are 202 and the minimum is 151, indicating some variables have missing figures whose effects are controlled by the STATA software in the regression analysis. Table 2 shows that the means for total debt leverage (TDL), long-term debt leverage (LDL) and short-term debt leverage (SDL) of $0.641,0.337$ and 0.3052 . The table also shows the mean of profitability (PROF), which is operating profit as a ratio of annual sales, as -0.123 . These negative mean confirm the Kenyan presidential report on state corporations (Republic of Kenya 2013: xii-xiv), which also indicated that the state-owned corporations have been making losses during this period. Interestingly, Table 2 also shows that liquidity (LIQ.), which is measured by current assets as a fraction of current liabilities, is 4.874, which is above the conventional 2.0 (Colin, Stephen, Randolph and Bradford 2012: 50-51). This result indicates high overall liquidity amongst the state-owned corporations. This pattern could be an indication of low external debt financing within the corporations and more of internal financing supported by the pecking order theory (Murray Z \& Vidhan K, 2008, p. 158). Table 2 shows the overall growth rate (GROW) of state-owned corporations, measured as a percentage change in total assets, at $15.65 \%$ over the period, indicating the need for financing the long-term investment expansions.

Correlation analysis: Table 3 presents the Pearson correlation coefficients $(r)$ for the panel data regression analysis variables used in the study. The table presents all the variables used in identification of the factors influencing debt financing within the state-owned corporations in Kenya. The symbols $* * *$, **, and * indicate significance at the 99\%, 95\% and 90\% levels, respectively. Table 3 shows that debt financing measures of total debt leverage (TDL) and short-term debt leverage (SDL) are significantly negatively correlated with the financial performance measures of profitability (PROF), but are very weak and not significant. The table also demonstrates that the financing leverage measures, TDL, LDL and SDL, are positively and significantly correlated with several measures of factors influencing debt financing. These factors include corporation size (SIZ), asset tangibility (TANG.), corporation risk (RISK), gross domestic product (GDP), inflation rate (INFL), interest rate (INT) and industry median (INDM). 
Table 3: Correlation analysis

\begin{tabular}{|c|c|c|c|c|c|c|c|c|c|c|c|c|c|c|c|c|}
\hline & TDL & LDL & SDL & PROF & SIZ & TANG & GROW & RISK & TAX & LIQ & NDTS & BKCY & GDP & INFL & INT & INGM \\
\hline TDL & 1 & & & & & & & & & & & & & & & \\
\hline LDL & $0.8415^{* * *}$ & 1 & & & & & & & & & & & & & & \\
\hline SDL & $0.6451^{* * *}$ & $0.1301^{*}$ & 1 & & & & & & & & & & & & & \\
\hline PROF & $-0.1395^{* *}$ & -0.0868 & $-0.1326^{*}$ & 1 & & & & & & & & & & & & \\
\hline SIZ & $0.383^{* * *}$ & $0.2958^{* * *}$ & $0.2842^{* * *}$ & $0.1331^{*}$ & 1 & & & & & & & & & & & \\
\hline TANG & $0.2592^{* * *}$ & $0.3065^{* * *}$ & 0.0408 & -0.0576 & $0.7536^{* * *}$ & 1 & & & & & & & & & & \\
\hline GROW & 0.0626 & -0.0429 & $0.1683^{* *}$ & 0.0037 & $0.1644^{* *}$ & 0.0402 & 1 & & & & & & & & & \\
\hline RISK & $0.3563^{* * *}$ & $0.2286^{* * *}$ & $0.3291^{* * *}$ & -0.0705 & $0.2452^{* * *}$ & $0.2308^{* * *}$ & -0.0435 & 1 & & & & & & & & \\
\hline TAX & -0.0569 & -0.0324 & -0.0588 & 0.0371 & $0.1274^{*}$ & 0.1054 & -0.0563 & 0.0099 & 1 & & & & & & & \\
\hline LIQ & -0.0724 & -0.0125 & $-0.1151^{*}$ & 0.0456 & 0.1025 & $0.1449^{*}$ & 0.0293 & $0.1953^{* * *}$ & -0.0112 & 1 & & & & & & \\
\hline NDTS & 0.0131 & -0.0203 & 0.0529 & 0.0115 & 0.0529 & 0.045 & -0.0188 & 0.0125 & -0.0036 & -0.0148 & 1 & & & & & \\
\hline вКСу & 0.0416 & -0.0128 & 0.0947 & 0.0166 & 0.0563 & 0.0412 & 0.0059 & 0.004 & -0.0025 & -0.0226 & 0.9678 & 1 & & & & \\
\hline GDP & $0.3149^{* * *}$ & $0.2239^{* * *}$ & $0.2609^{* * *}$ & -0.0488 & $0.7254^{* * *}$ & $0.5242^{* * *}$ & 0.0917 & $0.3063^{* * *}$ & $0.1197^{*}$ & $0.1242 *$ & -0.0271 & -0.0242 & 1 & & & \\
\hline INFL & $0.26^{* * * *}$ & $0.1546^{* *}$ & $0.2574^{* * *}$ & 0.0371 & $0.5885^{* * *}$ & $0.4122^{* * *}$ & $0.1637^{* *}$ & $0.2089 * * *$ & 0.0449 & 0.0626 & $0.1597 * *$ & $0.1659^{* *}$ & $0.234^{* * *}$ & 1 & & \\
\hline INT & $0.3983^{* * *}$ & $0.2941^{* * *}$ & $0.3143^{* * *}$ & -0.0129 & $0.9436^{* * *}$ & $0.6953^{* * *}$ & $0.169^{* *}$ & $0.2475^{* * *}$ & 0.0965 & 0.095 & 0.0485 & 0.049 & $0.6348^{* * *}$ & $0.58^{* * *}$ & 1 & \\
\hline INDM & $0.2702^{* * *}$ & $0.2933^{* * *}$ & 0.0808 & $-0.2959^{* * *}$ & $0.3777^{* * *}$ & $0.3674^{* * *}$ & -0.034 & $0.2309^{* * *}$ & -0.0712 & $0.1221^{*}$ & 0.0425 & 0.0453 & $0.286^{* * *}$ & $0.2651^{* * *}$ & $0.3566^{* * *}$ & 1 \\
\hline AGE & 0.0922 & 0.0816 & 0.0539 & 0.0945 & -0.0524 & $-0.1793^{* *}$ & $-0.1965^{* * *}$ & -0.0825 & 0.0212 & $-0.2306^{* * *}$ & -0.0687 & -0.0688 & -0.1077 & -0.0207 & -0.053 & $-0.1922^{* * *}$ \\
\hline
\end{tabular}

In addition, the table also highlights a non-significant positive correlation between corporation growth (GROW), non-debt tax shield (NDTS), probability of bankruptcy (BKCY) and corporation age (AGE), and TDL and SDL. On the other hand, Table 3 shows a negative correlation between corporation tax rate (TAX) and liquidity (LIQ), and all the financial leverage measures, though weak and not significant. This negative correlation of TAX and LIQ may be a sign of state-owned corporations pursuing the pecking order and agency debt-financing theories (Deesomsak et al., 2004, p. 394); (Öztekin \& Flannery, 2012, p. 91); (Jõeveer, 2013, p. 295). The table also shows that there is a significant positive correlation between firm-specific factors, such as SIZ, TANG, GROW and RISK, and macroeconomic factors, such as GDP, INFL, INT and INDM. The Pearson correlation coefficients (r) reported in Table 3 only show the pair-wise relationship between the variables used in the study regression analysis. 
Factors influencing debt financing within the state-owned corporations in Kenya: Table 4 represents the fixed effects, random effects and system-GMM panel data regression analysis results of the research model 1, which was applied to identify the factors influencing debt financing within the stateowned corporations in Kenya. It also presents the validity and reliability tests (i.e., $\mathrm{R}^{2}$, Wald chi2 (F), AR (1), AR (2) and Sargan test) for the models. The table presents the financial leverage variables (TDL, LDL and SDL) under three panel regression models: Fixed effects (FE), Random effects (RE) and system-GMM. $* * *, * *$, and $*$ indicate significance at the $99 \%, 95 \%$ and $90 \%$ level of confidence, respectively. Since, there is expectation of autocorrelation or serial correlation within the financial leverage variables under system-GMM, Table 4 includes the lagged values (L1) for the TDL, LDL and SDL. The Arellano-Bond AR (1) and AR (2) p tests are also included under system-GMM results, to test for autocorrelation or serial correlation within the first difference level and the second difference level, respectively. It is expected that autocorrelation should only exist at level one and not at level two. If there is autocorrelation in level one, then the system-GMM model should report AR (1) p<0.05 at $95 \%$ level of confidence, and if there is autocorrelation in level two, then AR (2) p>0.05 at 95\% level of confidence (Blundell \& Bond, 1998, p. 116; Bond, 2002, p. 149). Therefore, system-GMM estimator results are more efficient when AR (1) is significant and AR (2) is insignificant, and are believed to be more accurate than the fixed effects (FE) and the random effects (RE) results.

Table 4: Factors influencing debt financing regression model results

\begin{tabular}{|c|c|c|c|c|c|c|c|c|c|}
\hline \multirow[b]{2}{*}{ Variable } & \multicolumn{3}{|c|}{ Fixed effects (FE) } & \multicolumn{3}{|c|}{ Random effects (RE) } & \multicolumn{3}{|c|}{ System-GMM } \\
\hline & TDL & LDL & SDL & TDL & LDL & SDL & TDL & LDL & SDL \\
\hline Ll. & & & & & & & $0.9206^{* * *}$ & $0.9418^{* * *}$ & $0.7736^{* * *}$ \\
\hline PROF & $-0.0712^{* *}$ & -0.0038 & $-0.0713^{* *}$ & $-0.0798^{* * *}$ & -0.0067 & $-0.0889 * * *$ & $-0.0689 * *$ & 0.0004 & $-0.0863^{* * *}$ \\
\hline SIZ & $-0.3106^{* * *}$ & -0.0936 & $-0.2128^{* * *}$ & $-0.1430^{* * *}$ & -0.0186 & $-0.0559^{*}$ & 0.0064 & 0.0100 & -0.0079 \\
\hline TANG & $-0.6876^{* * *}$ & 0.1463 & $-0.8332^{* * *}$ & $-0.6694^{* * *}$ & 0.1372 & $-0.7356^{* * *}$ & $-0.2665^{* *}$ & 0.0293 & $-0.3201^{* * *}$ \\
\hline GROW & $-0.0011^{* * *}$ & -0.0001 & $-0.0011^{* *}$ & $-0.0013^{* * *}$ & -0.0001 & $-0.0012^{* * *}$ & $-0.0016^{* * *}$ & -0.0003 & $-0.0012^{* * *}$ \\
\hline RISK & $0.7238^{* * *}$ & -0.1771 & $0.9077^{* * *}$ & 0.8700 & -0.1105 & $0.9982^{* * *}$ & -0.2161 & 0.1716 & -0.1986 \\
\hline TAX & 0.0019 & 0.0098 & -0.0078 & -0.0016 & 0.0076 & -0.0104 & -0.0054 & 0.0022 & -0.0095 \\
\hline LIQ & $-0.0025^{* *}$ & 0.0005 & $-0.0030^{* *}$ & $-0.0034^{* * *}$ & -0.0001 & $-0.0035^{* * *}$ & -0.0011 & 0.0003 & -0.0020 \\
\hline NDTS & -0.0055 & 0.0034 & -0.0085 & -0.0044 & 0.0041 & -0.0097 & -0.0029 & 0.0036 & -0.0097 \\
\hline BKCY & 0.0192 & -0.0105 & 0.0289 & 0.0154 & -0.0129 & 0.0323 & 0.0088 & -0.0118 & 0.0318 \\
\hline GDP & -0.0093 & -0.0015 & -0.0070 & -0.0076 & -0.0016 & -0.0032 & 0.0127 & 0.0041 & 0.0090 \\
\hline INFL & $-0.0077^{* *}$ & -0.0003 & $-0.0072^{* *}$ & $-0.0062^{* *}$ & 0.0001 & $-0.0049 *$ & -0.0008 & 0.0006 & -0.0013 \\
\hline INT & 0.0121 & -0.0008 & 0.0120 & 0.0106 & -0.0001 & 0.0069 & -0.0042 & 0.0022 & -0.0062 \\
\hline INDM & 0.4450 & -0.0282 & 0.4102 & 0.2386 & 0.0529 & 0.1455 & 0.0567 & 0.0399* & 0.00414 \\
\hline FMC & 0.0008 & 0.0002 & 0.0006 & 0.0006 & 0.0001 & 0.0003 & -0.0001 & -0.0003 & -0.00002 \\
\hline AGE & 0.2989 & $0.2728^{*}$ & 0.0295 & 0.0319 & 0.0968 & -0.0644 & $-0.0660^{* *}$ & -0.0079 & $-0.0543^{* *}$ \\
\hline Constant & $7.1226^{* * *}$ & 1.5175 & $5.5079^{* * *}$ & $4.1194^{* * *}$ & 0.3369 & $2.1743^{* *}$ & $0.3020^{* *}$ & -0.2823 & $0.7098^{* *}$ \\
\hline observations & 168 & 168 & 168 & 168 & 168 & 168 & 160 & 160 & 160 \\
\hline $\begin{array}{l}\mathrm{R}^{2} \\
\text { Hausman } \\
\text { test- }\end{array}$ & 0.5661 & 0.1592 & 0.527 & 0.5412 & 0.1412 & 0.5994 & & & \\
\hline $\begin{array}{l}\text { Prob }>\text { chi2 } \\
\text { Prob }>F\end{array}$ & $0.0024^{* * *}$ & 0.9958 & -104.63 & $0.0024^{* * *}$ & 0.9958 & -104.63 & & & \\
\hline (Wald chi2) & $0.000^{* * *}$ & 0.930 & $0.000^{* * *}$ & $0.000^{* * *}$ & 0.9876 & $0.000^{* * *}$ & $0.000^{* * *}$ & $0.000^{* * *}$ & $0.000^{* * *}$ \\
\hline $\begin{array}{l}\text { AR(1) Pr }>z \\
\text { AR(Ministry } \\
\text { of Planning) }\end{array}$ & & & & & & & $0.090^{*}$ & $0.000^{* * *}$ & $0.000 * * *$ \\
\hline $\begin{array}{l}\mathrm{Pr}>\mathrm{z} \\
\text { Sargan test- }\end{array}$ & & & & & & & 0.537 & 0.810 & 0.593 \\
\hline Prob > chi 2 & & & & & & & 0.277 & 0.179 & 0.158 \\
\hline
\end{tabular}

The F test applied under fixed effects (FE) and random effects (RE), and the Wald test applied under system-GMM results are used to test the reliability of the estimators (coefficients) of the models, i.e., whether they are different from zero, symmetric and the estimator itself not seriously biased (Windmeijer, 2005, p. 26). The $\mathrm{p}<0.05$ values of $\mathrm{F}$ test and $\mathrm{p}$ (chi2) $<0.05$ of the Wald test indicate that the model coefficients or estimators are reliable at $95 \%$ level of confidence for both cases. Table 4 also 
shows the results for the Sargan test, which indicates the validity of the models under system-GMM by testing the over-identifying restrictions of the instruments (variables) (Bond, 2002, p. 149; Windmeijer, 2005, pp. 37-41). Higher values of p (chi2) indicate that the model is robust, but weakened by many instruments, and low values indicate that the model is not robust, but not weakened by many instruments. In addition, Table 4 shows the test results, which are applied to test the validity of fixed effects (FE) or random effects (RE). The Hausman tests whether the error terms (unique errors) are correlated with the regressors (coefficients). If the Hausman test is p (chi2) $<0.05$, then it shows that error terms are not correlated with the regressors, and, therefore, fixed effects (FE) results are valid (significant at 95\% level of significant). In contrast, if p (chi2) is $>0.05$, then it indicates that error terms are correlated with the regressors and random effects' (RE) results are more valid than fixed effects' (FE) results. Table 4 also shows the coefficient of determination $\left(R^{2}\right)$ results, which indicate the amount of variance of the dependent variable (financial leverage) explained by the independent variables (factors influencing debt financing), under the fixed effects (FE) and random effects (RE) models.

Table 4 shows some consistency on the results, which is a good test for robustness of the models and the variables (Lemma \& Negash, 2013, p. 1104). However, $\mathrm{R}^{2}$ results of long-term debt leverage under FE and RE models are below 2, which indicate that the amount of variance of LDL explained by the factors under the model is very low. The $p$ values of F-tests for FE and RE models are insignificant, indicating a low explanatory power of LDL variables under these models. In addition, the coefficients of the factors influencing LDL under the system-GMM are all insignificant, though the model passed the Arellano-Bond (AR) tests. Hence, the study focused on the results of the TDL and SDL to identify factors influencing debt financing within the state-owned corporations in Kenya. It is observed, from these empirical results in Table 4, that both corporation or firm-specific factors and macroeconomic factors have influence on debtfinancing strategies within state-owned corporations in Kenya.

Empirical results of firm-specific factors: Table 4 shows that the main firm-specific factors influencing debt financing within state-owned corporations in Kenya include profitability, corporation nature of asset (tangibility) and corporation growth. The table also highlights that corporation size, risk and liquidity, although not very strong, are also other firm-specific factors influencing debt financing within stateowned corporations in Kenya.

Profitability: The results in Table 4 confirms that profitability, measured by corporations' operating profit, as a ratio of annual sales, influences debt financing of state-owned corporations in Kenya negatively. The pecking order theory assumes that corporations with higher profitability will prefer internal financing to debt financing and, hence, a negative relationship is expected between profitability and debt financing levels (Baltacı \& Ayaydın, 2014, p. 49). Although, coefficients show a weak negative relationship of around -0.1 , they are significant at $95 \%$ level of confidence amongst all the models except for the system-GMM of LDL, which, as aforementioned, is not a strong model estimator in this study. However, it is a sign that the few state-owned corporations in Kenya, that may be using long-term debt financing, could be pursuing the trade-off theory. All the same, the negative relationship results are consistent with the findings in many previous studies (Alzomaia, 2014, p. 61; Antonczyk \& Salzmann, 2014, p. 145; Bauer, 2004, p. 164; Chakraborty, 2013, p. 117; Cortez \& Susanto, 2012, p. 130; Dang, 2013, p. 179; De Jong et al., 2008, p. 1961; Drobetz et al., 2013, p. 51; Gaud et al., 2007, p. 207; Jõeveer, 2013, p. 306; Smith, 2012, p. 157). Therefore, as highlighted earlier under types and extent of debt financing results, the negative relationship result of profitability indicates that state-owned corporations in Kenya use less of debt financing as a means of funding their investments. This may be because of a lack of total independence in decision making by the state-owned corporations' managers, to explore external debt financing sources, due to political influence on major decisions, such as debt financing (Palcic \& Reeves, 2013, p. 121). Another reason for less use of debt amongst the state-owned corporations in Kenya may be because the lack of efficient financial market and institutions in Kenya, to attract issue of debt securities by the state-owned corporations (Frank and Goyal 2005: 154; Randa and Gubbins 2013: 15).

Corporation nature of assets (tangibility): The study empirical results in Table 4 show a consistent strong negative influence of asset tangibility on financial leverage measures for all the models except for LDL, which reports a very low positive result. According to Baltacı and Ayaydın $(2014$, p. 50) the pecking order theory recognizes a negative relationship between tangibility and leverage, whereas the trade-off theory defends a positive one. Therefore, the significant negative strong coefficients of tangibility under the TDL and SDL, for all the models of FE, RE and system-GMM, are strong indications of the pecking order theory assumption that state-owned corporations with less collateral face higher information costs 
and, thus, prefer debt to equity (Baltacı \& Ayaydın, 2014, p. 54). Empirically, the study results of positive relationship with long-term leverage (LDL) are consistent with the previous empirical evidence of Lemma and Negash (2013, p. 1105) who argued that the relationship is generally negative and statistically significant for short-term leverage (SDL) while it is somehow positive for long-term leverage (LDL). This seems to suggest that some state-owned corporations in Kenya, with more tangible assets, tend to use their tangible assets as collateral to access long-term debt, and, hence, depend less on short-term debt. Further, in support of both the pecking order and agency theories, the study results may be an indication that state-owned corporations in Kenya, with less collateral and facing higher information costs prefer short-term debt to long-term debt and equity financing. On the contrary, state-owned corporations in Kenya, with more tangible assets and less information costs (reduced agency costs), prefer equity external financing to long-term debt. In addition, the implication of results of the pecking order theory is in line with the earlier implication of the profitability in this study, and other previous studies (Alzomaia, 2014, p. 61; Chakraborty, 2013, p. 117; Forte, Barros, \& Nakamura, 2013, p. 222; Gaud et al., 2007, p. 206; Smith, 2012, p. 157).

Corporation growth: As shown in Table 4, corporation growth is also a significant firm-specific factor that influences debt financing within state-owned corporations in Kenya. The results indicate that there is a significant negative influence of corporation growth on all the debt-financing (financial leverage) measures, though not strong, but very consistent throughout all the models. Except for LDL, the TDL and SDL results are significant under all the three models: FE, RE and system-GMM. Generally, theoretical studies suggest that corporation growth opportunities are negatively related with debt financing levels (Huang \& Song, 2006, p. 20). The negative relationship is in line with the trade-off and agency theories since the growth of corporations increases financial distress and agency cost of debt (Deesomsak et al., 2004, p. 393). Most previous studies have observed the negative relationship between the growth opportunities of a corporation and its debt financing levels (Chakraborty, 2013, p. 117; Deesomsak et al., 2004, p. 398; Kayo \& Kimura, 2011, p. 367; Lemma \& Negash, 2013, p. 1104; Mateev et al., 2013, p. 43). The results may be an indication that the cost of financial distress rises with expected growth within state-owned corporations in Kenya, forcing managers to reduce debt in the capital structure, in line with the trade-off theory. However, since the government is the major shareholder within the state-owned corporations in Kenya, the agency cost theory offers a better explanation of this negative relation. According to the theory, the state-owned corporations issue equity instead of debt to avoid conflict of interest between shareholders (government) and creditors when the values of future growth opportunities are higher (Kouki \& Said, 2012, p. 219; Moosa \& Li, 2012, pp. 115007-115005).

Corporation size: Although, size is not significant under the system-GMM, whose estimation procedures are more advanced, the fixed effects (FE) and random effects (RE) show significant results of the negative relationship between size and debt financing variables (TDL, LDL and SDL). The negative result is also highlighted under SDL by the system-GMM model, though not significant. However, the system-GMM shows a non-significant, very weak positive relationship under TDL and LDL. Therefore, the significant negative relationship results under the FE and RE can be an indication that debt-financing strategies of state-owned corporations in Kenya are also negatively influenced by their sizes. In support of a negative relationship between size and debt financing, Rajan and Zingales (1995, p. 1451) and Baltacı and Ayaydın (2014, p. 49) argued that asymmetric information problems are likely to be smaller in larger corporations. Hence, it would be possible for larger state-owned corporations in Kenya to issue new shares instead of debt financing without a reduction in their values, since most of them are not listed in the capital markets. Furthermore, the pecking order theory of debt financing also predicts that larger state-owned corporations, which are more diversified, will use less debt and, hence, expects that the size of the corporation will be negatively related to debt financing (Baltacı \& Ayaydın, 2014, p. 49). Some studies have also observed this negative relation of debt financing and corporation size. These studies include Rajan and Zingales (1995, p. 1423); Titman and Wessels (1988, p. 14); Gaud et al. (2007, p. 206); Smith (2012, p. 144); Majumdar (2012, p. 21) and Chakraborty (2013, p. 118).

Corporation risk: Table 4 shows mixed results for corporation risk as a factor influencing debt financing. The fixed effects (FE) and random effects (RE) models highlight a significant strong positive relationship between the volatility of operating profits (risk) of state-owned corporations in Kenya and their debtfinancing strategies, under the TDL and SDL. In contrast, under LDL, for both the FE and RE models, Table 4 shows a weak negative relationship, though not significant. The non-significant, weak negative relationship results are also highlighted by the system-GMM model, under the TDL and SDL. On the contrary, a non-significant and weak positive relationship result is observed under LDL. The debt 
financing of corporations is expected to decrease with an increase in earnings volatility, which is used as a measure of risk, since higher volatility of earnings increases the probability of financial distress as corporations may not be able to fulfil their debt-servicing contacts (Deesomsak et al., 2004, p. 394). This implies that a corporation's debt-financing level decreases with an increase in the corporation's risk, leading to an expected inverse relationship. Bauer (2004, p. 163) also accepted the fact that the relationship can be positive, especially when the variance of the corporation's assets increases and, in turn, reduces the systematic risk of the equity.

Studies like Bauer (2004, p. 172); Deesomsak et al. (2004, p. 398); Huang and Song (2006, p. 29); Antoniou et al. (2008, p. 77); De Jong et al. (2008, p. 1961); Frank and Goyal (2009, p. 32); Lim (2012, p. 197); Drobetz et al. (2013, p. 51); Forte et al. (2013, p. 364); Alzomaia (2014, p. 61) and Baltacı and Ayaydın (2014, p. 54), have found a negative relationship between corporation risk and debt financing. On the contrary, Gaud et al. (2005, p. 63); Foster and Young (2013, p. 7) and Lemma and Negash (2013, p. 1109) found both positive and negative relationships when they used different measures of debt financing level. Most of the studies, just like the results under system-GMM in Table 5.3, showed a negative relationship, although most of them were not strong and statistically significant ((Bauer, 2004, p. 172); (Deesomsak et al., 2004, p. 398); (Frank \& Goyal, 2009, p. 32).

Liquidity: Table 4 shows some consistent negative relationship between liquidity of the state-owned corporation and its financial leverage (debt financing). However, the long-term debt leverage (LDL) highlighted a positive relationship with liquidity of the state-owned corporations, under the FE and system-GMM models. The negative relation between debt financing and liquidity is commonly found in the capital structure literature (Smith, 2012, p. 157). Smith argued that this could be because more profitable corporations try to shun the adverse selection costs of outside debt, or because those that are profitable and rich in growth options seek to avoid the debt overhang problem. Empirically, studies such as Deesomsak et al. (2004, p. 398); Smith (2012, p. 157) and Mateev et al. (2013, p. 43) confirmed this negative theoretical relationship, while Gungoraydinoglu and Öztekin (2011, p. 1467), looking at some new international evidence, found a positive relationship between liquidity and debt financing. Therefore, according to the pecking order theory, the prominent negative relationship result can be an indication that the state-owned corporations in Kenya, with more liquid assets, use them as an internal source of funds instead of debt.

Empirical results of macroeconomic factors: Table 4 shows that debt financing strategies of stateowned corporations in Kenya are rarely influenced by the macroeconomic factors. The table only highlights some significant results on inflation (INFL), under the fixed effects (FE) and random effects (RE) models. The other macroeconomics factors, such as gross domestic product (GDP), interest rate (INT) and industry median (INDM) and financial markets conditions (FMC), highlighted insignificant results under all the models.

Inflation: Inflation is considered as one of the main indicators of a country's stability and an increase in the inflation rate causes uncertainty in economic conditions (Baltacı \& Ayaydın, 2014, p. 50). According to the results in Table 4, the inflation rate in Kenya generally influences debt financing of state-owned corporations negatively, though at a weak rate. The table confirms the inflation weak significant negative relationship with TDL and SDL, under all the three models. However, a very weak positive relationship is also highlighted, under the random effects (RE) and system-GMM models, with the long-term debt leverage (LDL). According to Gungoraydinoglu and Öztekin (2011, p. 1467), higher inflation decreases the benefits of debt financing because of higher bankruptcy costs of debt imposed on corporations. The negative relationship results confirm the argument of that higher inflation lowers debt financing levels and indicate that the state-owned corporations shun debt financing during periods of high inflation rates to reduce their bankruptcy costs. On the other hand, Jõeveer (2013, p. 295) maintained that the inflation can be positively related to debt financing due to higher real value of tax deductions on debt, which may be the case for LDL results. Previous studies have also not given consistent results on inflation. Gungoraydinoglu and Öztekin (2011, p. 1467); Drobetz et al. (2013, p. 67); Jõeveer (2013, p. 306); Antonczyk and Salzmann (2014, p. 146) and Baltacı and Ayaydın (2014, p. 54) found a negative relationship between inflation and debt financing. Interestingly, Frank and Goyal (2009, p. 26) found a positive relationship, in line with the Table 5.3 results under LDL.

Age: The other factor included under the explanatory variables for the three models was the age of the state-corporations, which was measured as the number of years in existence since incorporation. Table 4 
shows that age is a factor influencing debt financing negatively and significant for TDL and SDL, under the system-GMM model. However, for fixed effects (FE) and random effects (RE), the results are mixed and not significant. Others studies, such as Smith (2012, p. 155) and Bassey et al. (2014, p. 44), also observed a negative relationship between the corporation's age and its debt financing level, which is consistent with the theoretical expectation of the pecking order theory of debt financing. The system-GMM model results indicate that older state-owned corporations in Kenya use internal sources to fund their investments. In case internal funds are inadequate, they use equity financing more than debt financing. On other hand, young state-owned corporations, with less internal funds, are normally given grants or development funds by the government instead of using debt financing. Since system-GMM estimator is a more advanced tool for panel data regression analysis, it can be generalised that the LDL and SDL are the best models for identifying the factors influencing debt financing amongst the state-owned corporations in Kenya. The main factors, therefore, are profitability, tangibility, corporation growth and age, all negatively influencing debt-financing strategies of state-owned corporations, mostly, in line with the pecking order and the agency theories. Table 5 presents the questionnaire responses on the questions: a) what influences the corporation's borrowing; and b) who makes the borrowing decision within stateowned corporations in Kenya.

Table 5: Other factors influencing debt financing

\begin{tabular}{llll}
\hline & Frequency & Percent & Valid Percent \\
\hline a) What influences the corporation's borrowing & & & \\
$\quad$ Government policy & 4 & 21 & 21 \\
$\quad 12$ & 63 & 63 \\
$\begin{array}{l}\text { Market economic factors } \\
\quad \text { economic factors }\end{array}$ & 3 & 16 & 16 \\
$\quad 19$ & 100 & 100 \\
Total & 19 & & \\
b) Who makes borrowing decision & 2 & 11 & 11 \\
$\quad$ Government Officers (Cabinet Secretaries) & 16 & 84 & 84 \\
$\quad$ Corporation's board of directors & 1 & 5 & 5 \\
$\quad$ Others (all the above) & 19 & 100 & 100 \\
Total & & & \\
\hline
\end{tabular}

The main factors were the board of directors and market economic factors. The responses on who makes the decision on borrowing, indicated the board of directors at $84 \%$, government officer (Cabinet Secretary) at $11 \%$ and the finance manager at $5 \%$. This is a sign that the desired independence of management decisions, such as debt financing, under the new public sector financial management reforms, is yet to be achieved within the state-owned corporations in Kenya, since the major decision makers (i.e., board of directors and Cabinet Secretary) are political appointees. However, the responses as to which is the main factor influencing debt financing decisions, between the government policies and the market economic factors highlighted some independency in management decision making. $63 \%$ of the corporations agreed that they follow market economic factors in making debt-financing decisions. On the other hand, $21 \%$ of the corporations highlighted government policies, and $16 \%$ agreed that they follow both government policies and market economic factors.

\section{Conclusion and recommendations}

Prominently, the results from the advanced panel regression model estimator (system-GMM) only identified the three main factors, namely, profitability, asset tangibility and corporation growth. These factors were also highlighted significantly by the other panel regression model estimators (i.e., FE and $\mathrm{RE}$ ). Further, the models indicated that these factors negatively influence debt financing decisions within the state-owned corporations in Kenya. The other factors influencing debt financing within state-owned corporations in Kenya highlighted by the study results, especially under the fixed effects (FE) and random effects (RE), include corporation size, risk, liquidity, inflation rate and corporation age. The study results showed that the corporation size, liquidity and age had a significant negative influence, while corporation risk highlighted a positive influence and the inflation rate observed mixed results. 
In conclusion, the study accepted the null hypotheses $H_{0} 1, H_{0} 4$ and $H_{0} 5$, and rejected the null hypotheses $H_{0} 2, H_{0} 3$ and $H_{0} 15$, accepting their respective alternative hypotheses: $H_{1} 2$ : Corporation size influences debt financing negatively; $H_{1} 3$ : Asset tangibility influences debt financing negatively; and $H_{1} 15$ : Corporation age influences debt financing negatively. Further, the study rejected the hypotheses $H_{0} 6, H_{0} 7, H_{0} 8, H_{0} 9, H_{0} 10$, $H_{0} 11, H_{0} 12, H_{0} 13$ and $H_{0} 14$, and accepted their respective alternative hypotheses: $H_{1} 6:$ Corporation tax rate does not influence debt financing; $H_{1} 7$ : Liquidity does not influence debt financing; $H_{1} 8$ : Non-debt tax shield does not influence debt financing; $H_{1}$ 9: Probability of bankruptcy does not influence debt financing; $H_{1} 10$ : Gross domestic product does not influence debt financing; $H_{1} 11$ : Inflation rate influences debt financing both negatively and positively; $H_{1} 12$ : Interest rate does not influence debt financing; $H_{1} 13$ : Industry median does not influence debt financing; and $H_{1} 14$ : Financial market conditions do not influence debt financing. It can, therefore, be concluded that the main factors influencing debt-financing decisions within the state-owned corporations in Kenya are profitability, asset tangibility and corporation growth.

It can be concluded, from the study results, that the pecking order theory offers a more prominent explanation of debt financing decisions amongst the state-owned corporations in Kenya. However, the results show some elements of target adjustments and a strong influence of a politically appointed board of directors, which may be better explained by the agency theory. It is, therefore, recommended that a further study be done, using more data, to test the theories applicable in explanation of debt-financing patterns amongst the state-owned corporations in Kenya.

\section{References}

Agca, S., De Nicolò, G. \& Detragiache, E. (2007). Financial reforms, financial openness, and corporate borrowing: international evidence. IMF Working Papers, 1-47.

Agrawal, A. \& Jayaraman, N. (1994). The dividend policies of all-equity firms: A direct test of the free cash flow theory. Managerial and Decision Economics, 15(2), 139-148.

Alzomaia, T. S. F. (2014). Capital Structure Determinats of Publicly Listed Companies in Saudi Arabia. International Journal of Business \& Finance Research (IJBFR), 8(2), 53-67.

Antonczyk, R. C. \& Salzmann, A. J. (2014). Overconfidence and optimism: The effect of national culture on capital structure. Research in International Business and Finance, 31(0), 132-151. doi: http://dx.doi.org/10.1016/j.ribaf.2013.06.005

Antoniou, A., Guney, Y. \& Paudyal, K. (2008). The determinants of capital structure: capital marketoriented versus bank-oriented institutions. Journal of financial and quantitative analysis, 43(1), 59-92.

Baker, M. \& Wurgler, J. (2002). Market timing and capital structure. The Journal of Finance, 57(1), 1-32.

Baltacl, N. \& Ayaydın, H. (2014). Firm, Country and Macroeconomic Determinants of Capital Structure: Evidence from Turkish Banking Sector. EMAJ: Emerging Markets Journal, 3(3), 47-58. doi: 10.5195/emaj.2014.46

Bassey, N. E., Arene, C. J. \& Okpukpara, B. C. (2014). Determinants of Capital Structure of Listed Agro Firms in Nigeria. Economic Affairs: A Quarterly Journal of Economics, 59(1), 35-47. doi: 10.5958/J.0976-4666.59.1.004

Bauer, P. (2004). Capital structure of listed companies in visegrad countries. Prague economic papers, 2, 159-175.

Berger, A. N. \& Bonaccorsi di Patti, E. (2006). Capital structure and firm performance: A new approach to testing agency theory and an application to the banking industry. Journal of Banking \& Finance, 30(4), 1065-1102.

Berger, P. G., Ofek, E. \& Yermack, D. L. (2012). Managerial entrenchment and capital structure decisions. The Journal of Finance, 52(4), 1411-1438.

Blundell, R. \& Bond, S. (1998). Initial conditions and moment restrictions in dynamic panel data models. Journal of econometrics, 87(1), 115-143.

Bond, S. R. (2002). Dynamic panel data models: a guide to micro data methods and practice. Portuguese economic journal, 1(2), 141-162.

Byoun, S. (2008). How and when do firms adjust their capital structures toward targets? The Journal of Finance, 63(6), 3069-3096.

Calderón, C. \& Liu, L. (2003). The direction of causality between financial development and economic growth. Journal of Development Economics, 72(1), 321-334.

Campello, M. (2006). Debt financing: Does it boost or hurt firm performance in product markets? Journal of Financial Economics, 82(1), 135-172. 
Chakraborty, I. (2013). Does capital structure depend on group affiliation? An analysis of Indian firms. Journal of Policy Modeling, 35(1), 110-120. doi: http://dx.doi.org/10.1016/j.jpolmod.2012.02.006

Cortez, M. A. \& Susanto, S. (2012). The Determinants of Corporate Capital Structure: Evidence from Japanese Manufacturing Companies. Journal of International Business Research, 11, 122-134.

Dang, V. A. (2013). Testing capital structure theories using error correction models: evidence from the UK, France and Germany. Applied Economics, 45(2), 171-190.

Daskalakis, N. \& Psillaki, M. (2008). Do country or firm factors explain capital structure? Evidence from SMEs in France and Greece. Applied Financial Economics, 18(2), 87-97.

De Jong, A., Kabir, R. \& Nguyen, T. T. (2008). Capital structure around the world: The roles of firm-and country-specific determinants. Journal of Banking \& Finance, 32(9), 1954-1969.

DeAngelo, H., \& Masulis, R. W. (1980). Optimal capital structure under corporate and personal taxation. Journal of financial economics, 8(1), 3-29. doi: http://dx.doi.org/10.1016/0304405X(80)90019-7

Deesomsak, R., Paudyal, K. \& Pescetto, G. (2004). The determinants of capital structure: evidence from the Asia Pacific region. Journal of Multinational Financial Management, 14(4-5), 387-405. doi: http://dx.doi.org/10.1016/j.mulfin.2004.03.001

Dewenter, K. L. \& Malatesta, P. H. (2001). State-owned and privately owned firms: An empirical analysis of profitability, leverage, and labor intensity. The American Economic Review, 91(1), 320-334.

Drobetz, W., Gounopoulos, D., Merikas, A. \& Schröder, H. (2013). Capital structure decisions of globallylisted shipping companies. Transportation Research Part E: Logistics and Transportation Review, 52(0), 49-76. doi: http://dx.doi.org/10.1016/j.tre.2012.11.008

Fama, E. F. \& French, K. R. (2002). Testing trade-off and pecking order predictions about dividends and debt. Review of financial studies, 15(1), 1-33.

Forte, D., Barros, L. A. \& Nakamura, W. T. (2013). Determinants of the Capital Structure of Small and Medium Sized Brazilian Enterprises. BAR - Brazilian Administration Review, 10(3), 347-369.

Foster, M. D. \& Young, M. T. (2013). Capital Structure Determinants for Emerging Markets by Geographic Region. Journal of Applied Financial Research, 1, 55-87.

Fosu, S. (2013). Capital structure, product market competition and firm performance: Evidence from South Africa. The Quarterly Review of Economics and Finance, 53(2), 140-151. doi: http://dx.doi.org/10.1016/j.qref.2013.02.004

Frank, M. Z. \& Goyal, V. K. (2005). Trade-off and pecking order theories of debt. Handbook of empirical corporate finance, 2, 135-202.

Frank, M. Z. \& Goyal, V. K. (2009). Capital structure decisions: which factors are reliably important? Financial Management, 38(1), 1-37.

Fuerst-Waltl, B. \& Fuerst, C. (2012). Effect of inbreeding depression on survival of Austrian Brown Swiss calves and heifers. Journal of Dairy Science, 95(10), 6086-6092. doi: http://dx.doi.org/10.3168/jds.2011-4684

Gaud, P., Hoesli, M. \& Bender, A. (2007). Debt-equity choice in Europe. International Review of Financial Analysis, 16(3), 201-222.

Gaud, P., Jani, E., Hoesli, M. \& Bender, A. (2005). The Capital Structure of Swiss Companies: an Empirical Analysis Using Dynamic Panel Data. European Financial Management, 11(1), 51-69. doi: $10.1111 / \mathrm{j} .1354-7798.2005 .00275 . \mathrm{x}$

Greene, H. W. (2008). Econometric analysis (6th ed.). Upper Saddle River, New Jersey: Prentice Hall.

Gungoraydinoglu, A. \& Öztekin, Ö. (2011). Firm- and country-level determinants of corporate leverage: Some new international evidence. Journal of Corporate Finance, 17(5), 1457-1474. doi: http://dx.doi.org/10.1016/j.jcorpfin.2011.08.004

Guthrie, J. \& Olson, O. (1999). Debating developments in New Public Financial Management: The limits of global theorising and. Financial Accountability \& Management, 15(3/4), 209.

Hackbarth, D., Hennessy, C. A. \& Leland, H. E. (2007). Can the trade-off theory explain debt structure? Review of Financial Studies, 20(5), 1389-1428.

Harris, M. \& Raviv, A. (1988). Corporate control contests and capital structure. Journal of Financial Economics, 20(0), 55-86. doi: http://dx.doi.org/10.1016/0304-405X(88)90040-2

Harris, M. \& Raviv, A. (1991). The theory of capital structure. The Journal of Finance, 46(1), 297-355.

Houston, M. B. (2004). Assessing the validity of secondary data proxies for marketing constructs. Journal of Business Research, 57(2), 154-161. doi: http://dx.doi.org/10.1016/S0148-2963(01)00299-5

Huang, G. \& Song, F. M. (2006). The determinants of capital structure: evidence from China. China Economic Review, 17(1), 14-36. 
Jensen, M. C. (1986). Agency costs of free cash flow, corporate finance, and takeovers. The American economic review, 3, 323-329.

Jensen, M. C. \& Meckling, W. H. (1976). Theory of the firm: Managerial behavior, agency costs and ownership structure. Journal of Financial Economics, 3(4), 305-360.

Jiraporn, P., Kim, J. C., Kim, Y. S. \& Kitsabunnarat, P. (2012). Capital structure and corporate governance quality: Evidence from the Institutional Shareholder Services (ISS). International Review of Economics \& Finance, 22(1), 208-221. doi: http://dx.doi.org/10.1016/j.iref.2011.10.014

Jõeveer, K. (2013). Firm, country and macroeconomic determinants of capital structure: Evidence from transition economies. Journal of Comparative Economics, 41, 294-308.

Kayo, E. K. \& Kimura, H. (2011). Hierarchical determinants of capital structure. Journal of Banking \& Finance, 35(2), 358-371. doi: http://dx.doi.org/10.1016/j.jbankfin.2010.08.015

Kettl, D. F. \& Milward, B. H. (1996). The state of public management (1st ed.). United States of America: The Johns Hopkins University press.

King, M. R. \& Santor, E. (2008). Family values: Ownership structure, performance and capital structure of Canadian firms. Journal of Banking \& Finance, 32(11), 2423-2432. doi: http://dx.doi.org/10.1016/j.jbankfin.2008.02.002

Kouki, M. \& Said, H. B. (2012). Capital Structure Determinants: New Evidence from French Panel Data. International Journal of Business \& Management, $7(1)$.

Leland, H. E. (1998). Agency costs, risk management, and capital structure. The Journal of Finance, 53(4), 1213-1243.

Lemma, T. T. \& Negash, M. (2013). Institutional, macroeconomic and firm-specific determinants of capital structure: The African evidence. Management Research Review, 36(11), 3-3.

Lim, T. C. (2012). Determinants of Capital Structure Empirical Evidence from Financial Services Listed Firms in China. International Journal of Economics \& Finance, 4(3).

Majumdar, R. (2012). The Determinants of Indebtedness in Unlisted Manufacturing Firms in India: A Panel Data Analysis. MPRA Paper No. 43427, 1-32.

Majumdar, S. K. \& Chhibber, P. (1999). Capital structure and performance: Evidence from a transition economy on an aspect of corporate governance. Public Choice, 98(3-4), 287-305.

Mateev, M., Poutziouris, P. \& Ivanov, K. (2013). On the determinants of SME capital structure in Central and Eastern Europe: A dynamic panel analysis. Research in International Business and Finance, 27(1), 28-51. doi: http://dx.doi.org/10.1016/j.ribaf.2012.05.002

Ministry of Planning, N. D. A. V. (2012). Economic Survey 2012 Kenya National Bureau of Statistics Retrieved from http://www.knbs.or.ke/index.php?option=com_phocadownload\&view=category\&id=16:econo mic-survey-highlights\&Itemid=563.

Modigliani, F. \& Miller, M. H. (1958). The cost of capital, corporation finance and the theory of investment. The American economic review, 2, 261-297.

Modigliani, F. \& Miller, M. H. (1963). Corporate income taxes and the cost of capital: a correction. The American Economic Review, 53(3), 433-443.

Mokhova, N. \& Zinecker, M. (2014). Macroeconomic Factors and Corporate Capital Structure. Procedia Social and Behavioral Sciences, 110(0), 530-540. doi: http://dx.doi.org/10.1016/j.sbspro.2013.12.897

Moosa, I. \& Li, L. (2012). Firm-Specific Factors as Determinants of Capital Structure:: Evidence From Indonesia. Review of Pacific Basin Financial Markets \& Policies, 15(2), 1150007-11500011150007-1150017.

Murray Z, F. \& Vidhan K, G. (2008). Trade-off and pecking order theories of debt. Handbook Of Corporate Finance: Empirical Corporate Finance, 2, 135-202.

Myers, S. C. (1984). The capital structure puzzle. The Journal of Finance, 39(3), 574-592.

Myers, S. C. (2001). Capital structure. The Journal of Economic Perspectives, 15(2), 81-102.

Myers, S. C. \& Majluf, N. S. (1984). Corporate financing and investment decisions when firms have information that investors do not have. Journal of Financial Economics, 13(2), 187-221.

Ngugi, R., Amanja, D. \& Maana, I. (2006). Capital Market, Financial Deepening and Economic Growth in Kenya.

Njeru, K. (2013). Public Finance under Kenya's new Constitution. SID Constitution Working Paper No. 5. 2014, from http://www.sidint.net/docs/WP5.pdf

Oyesola, S. R. (2007). An Empirical Analysis of the Capital Structure of Selected Quoted Companies in Nigeria. International Journal of Applied Economics \& Finance, 1(1). 
Öztekin, Ö. \& Flannery, M. J. (2012). Institutional determinants of capital structure adjustment speeds. Journal of financial economics, 103(1), 88-112. doi: http://dx.doi.org/10.1016/j.jfineco.2011.08.014

Palcic, D. \& Reeves, E. (2013). State-Owned Enterprise Policy and the Loss of Economic Sovereignty: The Case of Ireland. Public Organization Review, 13(2), 117-130. doi: 10.1007/s11115-013-0232-0

Petersen, M. A. (2009). Estimating standard errors in finance panel data sets: Comparing approaches. Review of financial studies, 22(1), 435-480.

Rajan, R. G. \& Zingales, L. (1995). What do we know about capital structure? Some evidence from international data. The journal of Finance, 50(5), 1421-1460.

Randa, J., Smita, W., Apurva, S., Umutesi, A., Kennedy Mukuna, O., Nyamumbo, M. \& Sophie, R. (2013). Reinvigorating growth with a dynamic banking sector. World Bank Working Paper, 1, 1-82.

Republic of Kenya. (2013). Report of the Presidential Taskforce on Parastatal Reforms. Nairobi: Kenya Government Press Retrieved from http://www.cofek.co.ke/Report\%20of\%20The\%20Presidential\%20Task\%20force\%20on\%20 Parastatal\%20Reforms.pdf.

Rindfleisch, A., Malter, A. J., Ganesan, S. \& Moorman, C. (2008). Cross-sectional versus longitudinal survey research: concepts, findings, and guidelines. Journal of Marketing Research, 45(3), 261-279.

Smith, G. P. (2012). Capital Structure Determinants for Tax-Exempt Organisations: Evidence from the UK. Financial Accountability \& Management, 28(2), 143-163. doi: 10.1111/j.14680408.2012.00540.x

Struwig, F. W. \& Stead, G. B. (2013). Research: Planning, Designing and Reporting. South Africa: Pearson Education South Africa (Pty) Ltd 2013.

Stulz, R. (1990). Managerial discretion and optimal financing policies. Journal of Financial Economics, 26(1), 3-27.

Tangcharoensathien, V., Patcharanarumol, W., Ir, P., Aljunid, S. M., Mukti, A. G., Akkhavong, K. \& Mills, A. Health-financing reforms in southeast Asia: challenges in achieving universal coverage. The Lancet, 377(9768), 863-873. doi: http://dx.doi.org/10.1016/S0140-6736(10)61890-9

Titman, S. \& Wessels, R. (1988). The determinants of capital structure choice. The Journal of Finance, 43(1), 1-19.

Titman, S. \& Wessels, R. (2012). The determinants of capital structure choice. The Journal of Finance, 43(1), 1-19.

Windmeijer, F. (2005). A finite sample correction for the variance of linear efficient two-step GMM estimators. Journal of econometrics, 126(1), 25-51. doi: http://dx.doi.org/10.1016/j.jeconom.2004.02.005. 